\title{
Grundtvig som fortolker af Det Gamle Testamente
}

\author{
Af Jesper Høgenhaven
}

Grundtvigs fortolkning og brug af Det Gamle Testamente belyses ud fra hans historiske værker og deres direkte udsagn om Det Gamle Testamente og dets betydning. Grundtvigs bibelsyn fremstår her som "konservativt" på en række konkrete punkter, når det gælder tiltroen til de bibelske beretningers historicitet og oprindelse. I en diskussion med nyere positioner afvises det dog, at man kan tale om fundamentalisme hos Grundtvig. Brugen af gammeltestamentligt stof i Grundtvigs prædikener undersøges gennem en række eksempler, først og fremmest fra Vor Frelser-tiden. Endelig inddrages Grundtvigs salmedigtning og dens udstrakte anvendelse af gammeltestamentlige motiver.

Studier over Grundtvig som bibelekseget fylder ikke meget i Grundtvig-litteraturen. Det kan forekomme overraskende i betragtning af, hvor meget bibelfortolkning og bibelbrug fylder i Grundtvigs eget litterære værk. ${ }^{1}$

Henrik Wigh-Poulsen har i en studie over Grundtvigs brug af gammeltestamentligt motiv- og billedstof $i$ beskrivelsen af sin egen tid vist, hvordan Grundtvig etablerer en kontakt imellem det gammeltestamentlige profetiske landskab og sit eget danske landskab (WighPoulsen 1998). Udgangspunktet i Wigh-Poulsens artikel er RoskildeRiim fra 1814. Dette digt, der på titelbladet har en parafrase over Es 35,1-7, beskriver en vandring først gennem Roskilde by og siden gennem domkirken. Med rosen og kilden, de to elementer i bynavnet, som gennemgående symboler skaber digtet en sammenhæng imellem fortid og nutid. Wigh-Poulsen peger på flertydigheden i Grundtvigs brug af bibelske naturbilleder: På den ene side er naturen genstand for menneskets virke og dermed noget, der er (eller skal være) underlagt mennesket. På den anden side er naturen noget, der engang skal forklares og blive til den paradisiske natur. I forbindelse med betragtningen af naturen optræder der hos Grundtvig også en kritisk tendens rettet imod digteren som figur; og digteren vil i denne

En kortfattet, men instruktiv sammenfatning leverer Thodberg (1989). Jf. også Simonsen (1983). Grundtvigs syn på Det Gamle Testamente (med særlig henblik på Verdens Krønike (1814) er behandlet i Rosendal (2006). Jf. til Grundtvigs gendigtninger af gammeltestamentlige salmer Balslev-Clausen (2002a og 2002b). 
forbindelse også sige Grundtvig selv. For digteren er fascinationen af naturen og den jordiske skønhed nemlig en fristelse, som det gælder om at modstå.

En ganske særlig række af natur- og landskabsbilleder knytter sig til Grundtvigs hjemvenden til barndommens kristendom. Barndommens landskab bliver et udtryk for den kristne tro eller for troens oprindelige, overleverede og egentlige kerne. Hjemkomsten erfares som Guds indgribende, nyskabende handling $\mathrm{i}$ analogi med det gammeltestamentlige Israels hjemvenden til det forjættede land efter fangenskabet i Babylon. Ifølge Wigh-Poulsen kunne man ligefrem overveje med udgangspunkt i dette motiv at tale om en særlig variant af romantikken hos Grundtvig, nemlig en "hjemkomst-romantik" (i modsætning til en "længsels-romantik"), der i høj grad er formet af det gammeltestamentlige hjemkomst-motiv. Henrik Wigh-Poulsen peger her uden tvivl på en væsentlig pointe ved Grundtvigs fortolkning af Det Gamle Testamente: Grundtvigs skriftfortolkning udfolder sig i meget høj grad i en stadig vekselvirkning imellem fortid og nutid, hvor Grundtvig sammentænker eller samlæser gammeltestamentlige tekster og motiver og nutidig forkyndelse.

\section{Synet på Det Gamle Testamente i Grundtvigs historiske skrifter}

Ole Vind har i sin disputats om Grundtvigs historiefilosofi argumenteret for, at Grundtvigs bibelforståelse må kaldes fundamentalistisk. Grundtvigs skabelsesteologi forudsætter ifølge Vind "en fundamentalistisk bibellæsning, der betragter Genesis som bogstavelig sand historisk oplysning om menneskelivets oprindelse" (Vind 1992, 208). Vind formulerer synspunktet på følgende markante måde: "Den fundamentalistiske bibellæsning, som Grundtvig havde mødt som barn og som fæstnedes hos ham efter krisen i 1810, fastholdt han livet igennem - i stadig mere åbenbar modsætning til tidens åndsvidenskabelige hovedstrømninger" (ibid., 208-209). Hovedkilden er Grundtvigs Haandbog $i$ Verdens-Historien, hvor det for Vind er afgørende, at Grundtvig gennemgående betragter de bibelske beretninger som historisk troværdige. ${ }^{2}$ Vind fastslår, at han anvender betegnelsen fundamentalisme "i en idehistorisk betydning som udtryk for en bogstavelig læsning af de bibelske tekster som bevidst modsvar til moderne forsøg på historisk-kritisk læsning eller for eksempel evolutionslærens undergravning af den bogstavelige betydning" (ibid., 208). I denne forstand - fundamentalisme som et bevidst modsvar til 
bestemte moderne tankegange - mener Vind ikke, at ordet kan bruges meningsfyldt om for eksempel Augustins eller Luthers bibellæsning; til gengæld anser han det for særdeles dækkende for Grundtvigs syn, et syn, som Grundtvig ifølge Vind fastholder uændret livet igennem og i "stadig mere åbenbar modsætning" til samtidens hovedstrømninger.

Især det sidste synspunkt kan forekomme overraskende, når det sammenholdes med andre indflydelsesrige opfattelser af Grundtvigs bibelforståelse og bibelbrug. Det har i mange sammenhænge været gængs at tale om, at Grundtvig i en tidlig periode af sit forfatterskab i årene imellem $1810 \mathrm{og} 1824$ - var præget af et ortodokst bibelsyn med verbalinspirationslæren som omdrejningspunkt. Til gengæld er det en udbredt antagelse, at der i hvert fald efter 1825 sker et markant skifte hos Grundtvig, hvor den kirkelige anskuelse baner vejen for et friere forhold til bibelteksterne, og hvor det tidligere fokus på verbalinspirationen opgives, eftersom den sande kristendom ikke længere skal udledes af skriftens ord, men af det levende ord, der lyder i den kristne menighed gennem historien, ganske særligt ved dåb og nadver. Forestillingen om, at Grundtvig efter 1825 foretager en markant drejning bort fra den forudgående periodes bibelkristendom $\mathrm{i}$ retning af en kirkelig kristendom harmonerer umiddelbart dårligt med tesen om, at Grundtvig livet igennem var og forblev en slags bibelfundamentalist. ${ }^{3}$

Kim Arne Pedersen har for nylig forholdt sig kritisk til Vinds karakteristik af Grundtvig som repræsentant for fundamentalisme (Pedersen 2005). Pedersen foretager en nyttig skelnen imellem et teologihistorisk fundamentalisme-begreb på den ene side og et bredere idéhistorisk eller profanhistorisk fundamentalisme-begreb på den anden. I teologihistoriens perspektiv er "fundamentalisme" en bevægelse, der opstår i USA i slutningen af 1800-tallet. Den får sit navn efter et af bevægelsens teologiske hovedværker, 12-bindsværket The Fundamentals, der udkom i årene 1910-15; og den har et distinkt teologisk indhold, blandt andet udmøntet i en kraftig understregning af verbalinspirationen og i tilslutningen til en række traditionelle kristne læresætninger ("fundamentals") (Pedersen 2005, 89-91; Barr 1981, 2). I kirkehistorisk sammenhæng har den fundamentalistiske bevægelse karakter af et opgør i første række med liberalteologien, i anden række også med sekulariseringen af det amerikanske samfund. Det er det sidstnævnte træk ved bevægelsen, der danner afsæt for den mere omfattende brug af begrebet "fundamentalisme" til at dække en række strømninger inden for kristendom, islam, jødedom og hinduisme, den brug af begrebet, som Pedersen kalder den profanhistoriske funda-

3 Til denne terminologi, se belæg i Begtrup (1901). 
mentalisme-definition. Her bruges betegnelsen fundamentalisme om strømninger, der reagerer på aspekter ved moderniteten gennem programmer, der handler om bogstavtro læsning af religiøse tekster. Pedersen er - efter min mening med rette - generelt kritisk over for den meget omfattende brug af fundamentalisme-betegnelsen til at dække bevægelser og retninger, der historisk, kulturelt, ideologisk og sociologisk ligger langt fra hinanden. Han mener, at man med nogen ret kan tale om Grundtvig som fundamentalist i den snævrere teologihistoriske forstand, når det gælder perioden 1810-24; derimod giver det ikke mening at ville indplacere Grundtvig i det mere omfattende idéhistoriske fundamentalisme-begreb, som Vind forsøger. Det antimoderne træk, der kendetegner dette fundamentalisme-begreb, passer ganske enkelt ikke med Grundtvigs opfattelse af videnskab og historie.

I Kort Begreb af Verdens Krønike fra 1812 bygger Grundtvig som noget ganske naturligt sin indledende beskrivelse af verdens skabelse på beretningen i Første Mosebog. Det sker med en kort summarisk henvisning til den bibelske fremstillings sandfærdighed:

Den samme hellige Bog som lærer os, hvordan vi skulle leve paa Jorden, for at være Gud velbehagelige, og komme til ham efter Døden, Bibelen, giver os ogsaa en ligesaa skøn som sandfærdig Underretning om hin ældste Tid. Moses, en hellig Mand, paa hvem Herrens Aand hvilede, har, for mere end 3000 Aar siden, samlet de gamle Sagn om Verdens Oprindelse og de første Mennesker og af dem uddraget, hvad Aanden indvortes sagde ham, saa at være i Sandhed (US II, 187).

I de meget omfattende rettelser og anmærkninger, som Grundtvig ledsagede krøniken med, er der flere, der tager kampen op mod de mere kritiske opfattelser af de gammeltestamentlige teksters indhold. Således anfører Grundtvig som en kritisk note til sin egen tekst, at han ikke burde have undladt at omtale den døende Jakobs spådom "om Helten af Juda, der bandt sin Aseninde ved Golgatas Vinstok". Det udsagn, der tænkes på, er 1 Mos 49,11, hvor Jakob velsigner sine sønner efter tur og om Juda forkynder, at han binder sit æsel til vinstokken, et udsagn, som Grundtvig altså her tolker som en profeti om Kristi lidelse og død. I den forbindelse vender han sig udtrykkeligt mod den historisk-kritisk orienterede eksegeses synspunkt, der ser udsagnet i patriarkens mund som en hyldest til det fortidige judæiske kongehus eller som "et Digt i Virgils Maner til at smigre Kong Salomon". I "vore oplyste Tider", som Grundtvig ironisk skriver, betragtes det som forskrækkeligt endnu at ville finde en spådom om Messias i denne tekst, "hvor selv Herder og flere kristelige Mænd, bange for Tidens Spøgelse, have tillukt Øinene". Grundtvig har imidlertid vænnet sig af med frygten efter selv at have "leget 
Spøgelse", altså været under indflydelse af oplysningstidens historiske kritik. For Grundtvig er den rette forståelse af den gammeltestamentlige profeti givet med Jesu vidnesbyrd om Det Gamle Testamente: "Enten var Jesus en Løgner, eller ogsaa havde Abraham med Glæde i Aanden seet Kristi Dag (Joh. 8) og sikkerlig havde han ei fortiet sit glædelige Syn, om end ikke Jakob havde havt det samme" (US II, 392).

Grundtvig kommer ligeledes i anmærkningerne til Verdens Krønike ind på Danielsbogens beskrivelse af Nebukadnesars drøm om billedstøtten af guld, sølv, kobber, jern og ler, der knuses af en sten (Dan 2,31-45). Her mener Grundtvig, at han "med et Par Ord" burde have anmærket, hvorledes profeten forudså det romerske rige og dets skæbne (US II, 393). For Grundtvig rummer Danielsbogens beskrivelse en utvetydig henvisning til det romerske riges undergang og Guds riges komme i Kristus; og han tilføjer sarkastisk med adresse til bibelkritikken: "Mon Jøderne virkelig, for at føie de Kristne, skulde bagefter opdigtet denne Spaadom!!!" (US II, 394). Understregningen af det profetiske udsagns karakter af virkelig spådom afføder dernæst også en mere principiel bemærkning. Det strider nemlig ifølge Grundtvig imod almindelig historisk logik at betragte de gammeltestamentlige salmer og profetier, der forudsiger kommende tider, som tekster, der er opdigtet efter tildragelserne selv. For det første er der jødernes egen faste overbevisning om, at spådommene var gamle. Kun visheden om de profetiske udsagns høje alder og ægthed kan for Grundtvig forklare "det Vidunder, at Folket kunde vende tilbage til den Gud de havde forladt, og hænge saa fast ved hans Dyrkelse, som Historien om den makkabæiske Tid, ja om en Rad af Aarhundreder sandfærdig vidner." Hvis de gammeltestamentlige profetier virkelig, som kritikken mener, var affattet efter, at begivenhederne havde fundet sted, ville folket ikke have fæstet lid til dem. Endvidere henviser Grundtvig til den markante forskel imellem de gamle profeters sprog og udtrykskraft og den poetiske armod hos generationerne efter det babyloniske fangenskabs tid:

Hos de faa Profeter, som spaaede efter den Tid, se vi Poesiens Ild udbrændt, de ere kun gudfrygtige Moralister, og kun det forlenede Fremsyn udmærker dem; de apokryphiske Bøger og de 70 Fortolkere vidne om, at de livligste Aander havde skiftet Tungemaal; hos Sirach lære vi, hvad som da kaldtes Poesi, nemlig sligt høitravende Billedsprog, som ogsaa vi have givet dette Navn; men hvilken uhyre Forskel mellem det og de gamle Profeters Qvad. Nei havde der endnu været poetisk Gnist tilovers, da var vel Makkabæernes Heltetid ei blevet ubesjunget. Et Blik paa disse apokryphiske Bøger skulde ogsaa helbrede for det Galskab, at lade de gamle ebraiske Historier fremstaa 
ved deres Side. Dog, naar man lukker Øinene, nytter det ikke at Lyset skinner klart, det er alt hvad man kan sige (US II, 394).

Her ser vi altså Grundtvig argumentere med litterære og historiske grunde for sin antagelse af en traditionel tidsfæstelse og rækkefølge af de gammeltestamentlige skrifter: Den stilistiske forskellighed gør det indlysende umuligt, at de apokryfe jødiske skrifter skulle have den samme historiske baggrund som profetierne i Det Gamle Testamente. Disse profetier må derfor være ægte og stamme fra den langt ældre tid.

I Kort Begreb af Verdens Krønike (1812) møder vi således en Grundtvig, der er optaget af at forsvare de gammeltestamentlige teksters karakter af Kristus-profetier i overensstemmelse med kirkelig tradition og i modsætning til en historisk-kritisk eksegese, der er genstand for hans gentagne polemiske udfald. På denne baggrund er det bemærkelsesværdigt, at Grundtvig i den udførligere historiske fremstilling med samme titel (Kort Begreb af Verdens Krønike), der udkom to år efter, giver udtryk for en eksplicit bibel- og kanonkritik. For eksempel hedder det om Højsangen, at vi "uden Frygt" kan udelukke dette skrift fra kanon, "da den ei paa mindste Maade haver Vidnesbyrd i det Ny Testamente og er saalangt fra den Reenhed i Udtrykket, som vi af Psalmerne vide at den mest glødende Kiærlighed bevarede under Aandens Varetægt". ${ }^{4}$ Bent Rosendal har analyseret Grundtvigs brug og forståelse af Det Gamle Testamente i dette værk og når blandt andet frem til den klare konklusion, at man ikke på grundlag af Verdens Krønike fra 1814 kan udråbe Grundtvig til bibelfundamentalist. Hans bibel- og historiesyn er langt mere nuanceret. Dette viser sig ikke alene i den eksplicitte bibelkritik, men også i Grundtvigs forståelse af Guds ord, ikke som skrift, men som Gud selv (Rosendal 2006, 155-156).

Dette indtryk underbygges og forstærkes yderligere, når vi vender os til det noget senere værk Haandbog $i$ Verdens-Historien I fra 1833. I lighed med Krøniken fra 1812 og 1814 indledes håndbogen med en fremstilling af verdens skabelse og ældste historie, der bygger på beretningen i Første Mosebog. Bemærkelsesværdige i denne sammenhæng er imidlertid de indskudte kommentarer, Grundtvig ledsager fremstillingen med. Den bibelske beretning om verdens skabelse er

4

$V K$ 1814, 408-409. I skriftets fortale gør Grundtvig nærmere rede for sine kriterier, når det gælder bedømmelsen af de gammeltestamentlige skrifter: Kanoniske bøger i egentlig forstand er alene de skrifter, som Jesus og Det Nye Testamente bevidner. Mosebøgerne, de seksten profetbøger og Salmernes Bog "skal troes paa Ordet", de skrifter, som Kristus og apostlene bruger (uden direkte at give dem vidnesbyrd som Guds ord), "skal troes i Tingene", medens de øvrige gammeltestamentlige skrifter skal betragtes som blot menneskelige bøger (ibid., XXXI-XXXII). Jf. Rosendal (2006, 151). 
ifølge Grundtvig naturligvis ingen menneskelig øjenvidneberetning, men en guddommelig åbenbaring; det er sådan, jøderne tror på deres hellige skrift. Herefter vælger Grundtvig nu med det samme at problematisere selve åbenbaringsbegrebet:

Hvorvidt nu derved skal forstaaes Andet end det med Guddoms-Aande oplivede Menneskes Grund-Anskuelse af Skabningen og Skaberen, derom kan Man tvistes, men guddommelig er alle Dage denne Forestilling om Verdens Ophav, thi den er, som ingen anden, baade Guddommen værdig og passende til Menneske-Aandens høieste Flugt og til Hjertets dybeste Rørelser uden at selv Spidsfindigheden har kunnet opdage et eneste Træk deri, som streed mod en uncegtelig Sandhed; thi selv om det var en saadan, at somme Bjerge er langt ældre end den Slægt, der begynder med Adam, da bortfaldt derved vel endeel Bøger af vore Skrift-Kloge, men ikke en Tøddel af SkabelsesBogen! (US VI, 45).

Grundtvig opererer her med forskellige alternative opfattelser af den bibelske beretning som åbenbaring. Og det er tydeligvis en vigtig pointe, at der ud over den traditionelle forestilling om en direkte, specifik guddommelig åbenbaring også kan tænkes en åbenbaring i mere generel, omfattende forstand, nemlig en indsigt i skabelsen, der følger med guddoms-åndens oplivelse af det skabte menneske, altså en åbenbaring, der i grunden hører sammen med selve skabelsen og er lige så universel som denne. For Grundtvig er den egentlige eller afgørende værdi i skabelsesbogen ikke er knyttet til antagelsen af en åbenbaring i traditionel supranaturalistisk forstand. Også hvis man forstår den bibelske fortælling som et udtryk for en menneskelig grundanskuelse af skabningen og skaberen - der altså ikke bygger på en specifik åbenbaring, men på den guddomsånde, der kendetegner det sandt menneskelige i det hele taget - fremstår forestillingen om Gud som skaber og verden som hans skabning som guddommelig. Kim Arne Pedersen henviser da også til denne passage som et tydeligt vidnesbyrd om den åbenhed, man finder hos Grundtvig i 1833 i forhold til at forstå skabelsesberetningen som en myte (Pedersen 2005, 115-116).

Udsagnet står ikke isoleret $\mathrm{i}$ forfatterskabet. Tværtimod viser det sig at harmonere med en række tilsvarende kommentarer, hvori Grundtvig udtrykkelig lægger afstand ikke bare til verbalinspirationslæren, men også generelt til nødvendigheden af at tillægge de gammeltestamentlige tekster en historisk sandhedsværdi. Medens Grundtvig i sine tidligere fremstillinger gjorde markant polemisk front imod rationalismens kritiske bibeleksegese, gælder hans opgør i Haandbog $i$ Verdens-Historien såvel ortodokse tilhængere af verbalinspirationslæren som deres rationalistiske kritikere. I grunden synes 
begge grupper for Grundtvig at befinde sig på samme side. I forbindelse med skabelses- og syndefaldsfortællingen gør Grundtvig således gældende, at der har været to måder at forstå denne på, enten "bogstavelig som en aabenbaret Historie" eller som "en mærkelig Mythe fra den graa Old-Tid". I virkeligheden er der dog i Grundtvigs øjne tale om to opfattelser, der bygger på den samme - skæve forudsætning og dermed i sidste ende bliver sider af samme sag. Både den bogstavelige opfattelse af den gammeltestamentlige beretning som åbenbaret historie og opfattelsen af teksten som myte har nemlig som forudsætning, at jødernes hellige skrift sættes i en skæv forbindelse med den kristne tro. Netop dette har imidlertid "vore Skrift-Kloge siden Reformationen" gjort med flid (US VI, 46).

De skriftkloge er her tydeligvis ikke rationalisterne, men derimod hele den efterreformatoriske teologiske tradition, der udnævner den bibelske syndefaldsberetnings bogstavelige historicitet til en nødvendig forudsætning for den kristne tale om oprejsning og frelse. Den rationalistiske nedskrivning af beretningen til "en mærkelig Mythe fra den graa Old-Tid" er tydeligvis kun en slags negativ afspejling af den ortodokse position på dennes egne betingelser. Den samme problematik kommer tydeligt til udtryk i Grundtvigs bemærkninger til slægtstavlerne i 1 Mos 5, hvor han ligeledes finder, at stridighederne imellem konservative og kritiske eksegeter udspiller sig på præmisser, der i bund og grund er forfejlede. I denne sammenhæng kan Grundtvig direkte gøre polemisk front mod ortodoksiens lære om Bibelens verbalinspiration. Siden reformationen har telogerne haft "den Grille, at Jødernes Hellige Skrift var Klippen hvorpaa den Christne Kirke var bygt, og at paa den skulde de slaae med deres Pen som en Moses-Stav, saa der sprang en Troes-Artikel ud af hvert Bogstav" (US VI, 50).

Her distancerer Grundtvig sig klart fra forestillingen om, at der i direkte forstand kan eller skal udledes kristne trosartikler af Det Gamle Testamente, som - her ikke mindst markeret gennem betegnelsen jødernes hellige skrift - anbringes på sit bestemte sted inden for rammerne af en historisk forståelse. Dette forbehold betyder dog på ingen måde, at de gammeltestamentlige tekster mister deres centrale betydning. Den vægt, Grundtvig tillægger de bibelske fortællinger, dokumenteres med al tydelighed gennem deres fremtrædende placering i hans egen historiske fremstilling. Han kan da også slutte den allerede citerede passage med en bemærkning om, at den historiske efterretning, som er indeholdt i slægtsregistret, "kan vi skatte som vi skiønne, naar vi kun huske, at aldeles ørkesløst staaer sikkert Intet i den Bog" (US VI, 50).

Det er også ubestrideligt, at Grundtvig i et meget vidt omfang anser de gammeltestamentlige tekster for at have historisk kildeværdi; 
hans faktiske brug af Det Gamle Testamente kan i denne forstand godt kaldes konservativt både set med samtidens og eftertidens øjne. Det gælder Haandbog $i$ Verdens-Historien i lige så høj grad som de tidligere fremstillinger; også her argumenterer Grundtvig i øvrigt flittigt med historiske og naturvidenskabelige grunde for beretningernes gyldighed. Således betragter han beretningen om de fire paradisfloder (1 Mos 2,10-14) som et autentisk vidnesbyrd om, hvordan verden tog sig ud ved tidernes begyndelse: De tre floder identificerer han med Ganges, Eufrat og Nilen, hjemsteder for tre betydningsfulde oldtidskulturer, floder, der med Grundtvigs ord " $\mathrm{i}$ Old-Tiden spillede saa udmærket en Rolle som store Patte-Flasker for Folkene i Barndommen"; den fjerde og sidste af paradisstrømmene er han tilbøjelig til at identificere med Amazonfloden; "det var ikke saa urimeligt, om Jorden engang i sine unge Dage havde hængt rigtig sammen" (US VI, 47-48).

Man må med andre ord give Hejne Simonsen ret i den iagttagelse, at Grundtvig principielt accepterer den historisk funderede bibelkritik samtidig med, at han i sine konkrete resultater fremstår som en yderst konservativ ekseget (Simonsen 1983, 23). Dette udsagn har også gyldighed for Grundtvigs forståelse af Det Gamle Testamente som vidnesbyrd om historien. Om en fundamentalistisk bibelforståelse hos Grundtvig giver det derimod ikke mening at tale. Og at Grundtvig skulle have fastholdt en fundamentalistisk bibellæsning i stadig mere åbenbar modsætning til tidens hovedstrømninger, er et udsagn, som direkte modsiges af den større vægt, der i Grundtvigs senere skrifter lægges på at nuancere åbenbaringsbegrebet og placere ortodoksiens og rationalismens skriftkloge på samme linje.

\section{Brugen af gammeltestamentlige tekster i Grundtvigs pradikener}

Særlig i Grundtvigs prædikener fra hans tid ved Vor Frelser Kirke (1822-26) fylder Det Gamle Testamente helt konkret meget i form af et meget omfattende antal henvisninger og referencer til den første del af Bibelen, ikke mindst $i$ betragtning af, at antallet af foreskrevne gammeltestamentlige læsestykker i datidens alterbog var yderst beskedent. Brugen af det gammeltestamentlige stof synes grundlæggende båret af en fast og urokkelig overbevisning om, at der er en overordnet sammenhængende mening i skriften. Således kan Grundtvig ganske ubesværet lade den gammeltestamentlige tekst udtrykke og tolke indholdet $\mathrm{i}$ den kristne forkyndelse. Denne overbevisning kan aflæses af en skriftbrug, hvor citater fra af Det Gamle Testamente sættes direkte og uformidlet ind i en kristen teologisk sammenhæng. 
I Grundtvigs prædiken til 1. søndag i advent 1822 er udgangspunktet Salme 118, som Grundtvig citerer i prædikenens begyndelse: "Denne er Dagen som Herren gjorde; lader os frydes og glædes i den". Salmistens opfordring til lovsang sætter Grundtvig uden videre i forbindelse med opfyldelsen af alle de gammeltestamentlige profetier, som der henvises til gennem et par summariske allusioner til 1 Mos 12,1-3 (velsignelsen til Abraham) og Salme 72:

Saaledes, mine Venner! sang Psalmisten i det Gamle Testamente, som vi kan læse i den 118de Psalme, og hvad var det vel som bevægede hans Hjerte og oplod hans Læber til de Jubel-Toner, hvad var det vel, uden Synet i Aanden af den store Naadens og Frelsens og Velsignelsens Dag, som Abraham alt efter Jesu eget Vidnesbyrd med Glæde forudsaae, Dagen da Gud vilde opvække ham den hellige Sæd, i hvem alle Jorderigs Slægter skulde velsignes, ja hvis Navn, som David synger, i den 72de Psalme, skulde, saalænge Solen skinner, forplantes fra Børn til Børne-Børn, saa de velsignede sig Alle i ham (GP I, 53).

Den forbindelse imellem den gammeltestamentlige salme og Jesu Kristi dag, som Grundtvig her så ubesværet knytter, kalder dog på en begrundelse. Den kommer i samme prædiken i form af et dobbelt bevis: Grundtvig henviser dels til Jesu egen udlægning af salmens ord i Det Nye Testamente, dels til Faderens frelsende gerning gennem den kristne menigheds historie, som udgør en stadfæstelse af profetien:

thi disse Ord veed vi at Jesus udtrykkelig udlagde om sig, og det er aabenbart, at den almægtige Gud, som haver alting at styre at raade, Han haver selv i Tidernes Løb høirøstet udlagt dem om Jesus den Christus, thi det er jo unægtelig at denne Jesus, som de Ypperstepræster, Pharisæer og Skriftkloge med alle Folkets Høvdinger forkastede, og overantvordede til Dødens Dom, at han, med sit Ord blev dog Hovedhjørne-Stenen i det aandelige Guds Huus og Tempel, som nu opreistes paa Jorden, og som, under Navnet af Frelserens Kirke haver trodset Tidernes Vandløb og Storme, ja Helvedes Porte, og skal, som vi stadelig troe, paa hans Ord, fremdeles med Spiret i Sky trodse dem til Dagenes Ende (GP I, 53).

Passagen, der jo indeholder et umiskendeligt ordspil på Vor Frelsers kirkes navn og en henvisning til kirkebygningens mest karakteristiske arkitektoniske træk ("med Spiret i Sky"), rummer kun i mindre grad den polemiske tone, som går igen i mange af Grundtvigs prædikener fra Vor Frelser-tiden; højst kan vi i henvisningen til ypperstepræster, farisæer og skriftkloge ane en hentydning til Grundtvigs modstandere, som netop ofte optræder under navnet skriftkloge i disse prædikener. Under denne betegnelse polemiserer Grundtvig jæunligt mod en 
modstander, der tydeligt bærer rationalismens og den historiske bibelkritiks kendetegn.

I en fredagsprædiken fra 1825, hvor Grundtvig lægger den gammeltestamentlige Salme 1 til grund som prædikentekst, bliver den "hellige Sangers" stemme uden videre begrundelse identisk med den kristne fromheds stemme. Den gammeltestamentlige salmists erfaring af lykke og salighed kan derfor på umiddelbar måde være de kristne til trøst og opmuntring. Vilkårene for den, der følger Guds vej midt i en ugudelig verden, er nemlig til alle tider de samme (GP III, 59-61).

Her er den historiske afstand imellem den gammeltestamentlige tekstverden og den kristne menigheds verden tilsyneladende ophævet eller bortfaldet $i$ et enhedssyn. Det betyder imidlertid ikke, at Grundtvig tænker ahistorisk om Det Gamle Testamentes plads i en kristen sammenhæng. Tværtimod kan han $\mathrm{i}$ anden sammenhæng betone netop den historiske afstand som baggrund for at fremhæve den gammeltestamentlige profetis betydning. På trinitatis søndag 1823 indleder Grundtvig således sin prædiken med et citat fra Første Kongebog 8: "Mon Gud skulde sandeligen boe paa Jorden, see, Himlene og Himlenes Himle kan ikke begribe dig, langt mindre dette Huus som jeg haver bygt". Disse ord af Salomo skal nu ifølge Grundtvig netop forstås i deres historiske sammenhæng; ord som disse er nemlig rettet imod "den almindelige hedenske Vildfarelse", at et jordisk tempel kan være bolig for verdens skaber. Her gælder det om nutidens kristne, der lige fra barndommen "uden vort Vidende ja maaskee imod vor Villie" har været udsat for Guds ord "forplantet fra Slægt til Slægt" og gennem ordet fået "høiere Tanker og klarere Kundskab om Gud", at de sjældent overvejer, hvad der hørte til at tale som Salomo, Esajas og alle profeterne $\mathrm{i}$ hedenskabets dage. I sin tid var denne tale kun mulig, fordi profeterne var drevet af "en høiere Aand", altså Helligånden. Dette historiske perspektiv er det ifølge Grundtvig nødvendigt at understrege, fordi det gerne overses: "Vi smile for det Meste kun fornemt ad vore Fædres og alle Hedningers Daarlighed, uden at betænke, hvad det er, som ene haver gjort os klogere" (GP I, 283). På den baggrund er det derfor heller ikke noget under, fortsætter Grundtvig, "om man engang opdagede, at vi i Grunden var slet ikke klogere, men at det kun syndes saa, fordi Vildfarelsen var med Konst forfinet, Hedenskabets Mørke ved Christendommens Lys fortyndet til en Dunkelhed, der i Muldvarpers Øine var stærk Oplysning”( GP I, 283).

Hermed har Grundtvig fundet et afsæt til et angreb på "Verdens nærværende Viisdom" (GP I, 284), som han tolker som en forfinet variant af hedenskabets dårskab; også den samtidige visdom vil nemlig bygge Gud et hus - ikke af træ og sten, men af menneskers ord og tanker - og lade den menneskelige fornufts evne til at forstå og begribe 
det guddommelige være det endelige sandhedskriterium. Her er det som andre steder i Vor Frelser-prædikenerne tydeligt, at Grundtvigs (tænkte) modstander er den rationalistiske kristendomsforståelse og teologi.

I Grundtvigs tolkning af teksten og tempelmotivet fra Første Kongebog 8 indgår, hvad Grundtvig selv udtrykkelig betegner som en historisk dimension. Det er imidlertid klart, at den historiske distance imellem tekstens tid og nutiden her først og fremmest benyttes som et retorisk greb. Afstanden imellem dengang og nu viser sig nemlig kun at være tilsyneladende eller i hvert fald kun en relativ afstand, der gælder noget ydre: Hedenskabet er kun tilsyneladende forsvundet, det har antaget mere forfinede ydre former og forklæder sig nu som oplysning. I virkeligheden - det er Grundtvigs pointe - er der ingen afstand imellem det gamle og det nye hedenskab.

$\mathrm{Vi}$ har set en række eksempler på, hvordan Grundtvig i sine prædikener kan tolke den gammeltestamentlige tekst bogstaveligt eller historisk og sætte tekstens udsagn i umiddelbar forbindelse med den kristne forkyndelse og den kristne menigheds situation. Teksterne handler i denne tolkning om det, de selv siger. Samtidig forbindes teksternes udsagn - læst direkte og for så vidt bogstaveligt - med den kristne menighed og dennes situation på Grundtvigs egen tid. Teksterne bliver med andre ord til direkte, aktuelle kommentarer, der taler ind i Grundtvigs og menighedens egen virkelighed. En anden måde at forholde sig til Det Gamle Testamente på møder vi i en prædiken til 5. søndag efter trinitatis 1823 , hvor Grundtvig udlægger visionen om det nye Jerusalem fra Ezekiels Bog. Her bliver tolkningen allegorisk, idet teksten hævdes at dreje sig om noget andet end det, som den på det umiddelbare, bogstavelige plan udsiger.

Naar Propheten Ezechiel, fra sin Bogs det 40de til Enden beskriver det store Syn, hvori ham blev viist det nye Jerusalem, med Herrens Tempel og alle Israels Boliger i det hellige Land, da føler enhver opmærksom Læser, at Talen er om noget langt Mere og Høiere end hvad der udvortes synlig og legemlig skedte, da en Deel af Herrens Folk vendte tilbage fra Babel til deres Fædres Land, og opreiste Staden og Templet igien af Gruset. Meget af Beskrivelsen er os vel endnu saa dunkel, at det hverken vilde være til Oplysning eller Opbyggelse at anvende det paa Guds aandelige Stad, som er og skal komme, paa vor Herres Jesu Christi Kirke og Menighed, hvilken vi bestandig skimte bag Billed-Sløret, som Maanen bag Skye; men dog er det anderledes med en Deel deraf, og især med Talen i det $47 \mathrm{de}$ Kapitel, hvor Propheten melder om de tvende Floder som han saae udspringe fra Herrens Helligdom, og voxe, under deres Løb saa høit, at de gik alle over Hovedet. Disse Floder betegne umiskiendelig de tvende store Aabenbaringer, den Prophetiske i det Gamle, og den Apostoliske i det Ny Testamente, disse aandelige Strømme af sand Guds-Kundskab, 
som udsprang fra Israels Helligdom, fra Zions Klippe tog deres Løb fra Østen til Vesten, fra Syden til Norden, fortsætte det endnu, og skal først ende det, naar det er fuldkommet til Guds Folks Glæde og da vende tilbage til deres himmelske Udspring, til Livets og Lysets den evige Kilde (GP I, 316-317).

Her bliver den gammeltestamentlige tekst $i$ en vis forstand transparent: Bag sløret skimtes bestandig "Guds aandelige Stad" eller Kristi kirke og menighed. De ydre, konkrete begivenheder, som de gammeltestamentlige tekster beretter om - de fordrevne israelitters hjemvenden til Jerusalem og genopførelsen af templet - danner et "Billed-Slør", gennem hvilket den kristne sandhed hele tiden er synlig. Samtidig er teksten imidlertid ikke kun klar, men også dunkel. Det er ikke alle enkeltheder, der fremstår med samme klarhed. Den kristne sandhed ses "som Maanen bag Skye". Der bliver i den forstand tale om et komplekst forhold imellem det skjulte og det åbenbare, imellem dunkelhed og transparens. Sandheden bliver her en genstand ikke for direkte erkendelse, men derimod for anelse, den skimtes snarere, end den ses.

Mere fremtrædende end denne allegoriske tolkning er dog den typologiske model, som vi møder gentagne gange i Grundtvigs inddragelse af Det Gamle Testamente i prædikenerne. ${ }^{5}$ Således kan Grundtvig i direkte forlængelse af Første Korinterbrev 10 tolke mannaen, som Israels børn spiste i ørkenen, som en type på det egentlige himmelbrød, ligesom vandet, der sprang af klippen, var en type på det sande levende vand eller den åndelige drik, som Kristus skænker (GP I, 128). Denne klassiske tolkningsmodel bliver også flere gange direkte tematiseret, idet Grundtvig selv fremhæver den gammeltestamentlige begivenheds karakter af forbillede. En karakteristisk formulering finder man $\mathrm{i}$ en prædiken til fastelavn 1825, hvor udgangspunktet er 1 Pet 3,18-22, der sammenstiller beretningen om syndfloden og arken med den kristne dåb. Grundtvig bygger her $\mathrm{i}$ meget høj grad direkte på den nytestamentlige teksts egen udtryksmåde. Den sammenligning, som Første Petersbrev foretager imellem den kristne dåb og arken og syndfloden, har på flere måder virket anstødelig på nutidens kristne, konstaterer Grundtvig. Dels var hele syndflodsfortællingen i Det Gamle Testamente en tale, som man helst ville glemme, da den er under angreb fra de vantro, der anser den for historisk umulig. Dels er de kristne selv ifølge Grundtvig blevet fremmede for apostlens betragtning af Det Gamle Testamentes begivenheder "som Forbilleder paa Guds Gierninger i det Ny". Disse to aspekter hører imidlertid nøje sammen. Har man først bildt sig ind,

5 Typologiske tolkninger af gammeltestamentlige figurer og begivenheder spiller også en vigtig rolle i Grundtvigs historiske fremstillinger. Jf. Rosendal (2006, 147-149). 
at det, der i Det Gamle Testamente fortælles om arken og syndfloden, er "halvveis en Fabel", bliver apostelens tale uforståelig, "da den aabenbar forudsætter det Modsatte, forudsætter, at Noas Frelse i Arken er ligesaa virkelig og sandfærdig, som vores Frelse ved Daaben i Christi Kirke, og at hin er et Forbillede paa denne" (GP III, 96). For Grundtvig er det altså her af væsentlig betydning, at de gammeltestamentlige begivenheder fastholdes som virkelige og sandfærdige $\mathrm{i}$ deres egen ret samtidig med, at de i kraft af den typologiske model făr en henvisende karakter.

Helt på samme linje er Grundtvig i sin prædiken til Septuagesima 1823. Også her er udgangspunktet en nytestamentlig tekst, der forholder sig tolkende til Det Gamle Testamente, nemlig 1 Kor 9,2410,5 , hvor begivenhederne under israelitternes vandring i ørkenen udlægges som advarende eksempler for de kristne. Apostelen vil have de kristne til i "disse store, vidunderlige Tildragelser" at se "et Forbillede paa Herrens Førelser med dem, med sit christnede Folk i det Nye Testamente." At der er tale om virkelige, stedfundne begivenheder, er en klar forudsætning: " Apostelen forudsætter naturligviis at de som høre ham, troe det er Sandhed, hvad Skriften fortæller, det forudsætte vi nødvendig ogsaa, naar vi for Menigheden udlægge hans Tale", siger Grundtvig med den tilføjelse, at han kun udtrykkelig fremhæver dette forhold, fordi hans samtid har udnævnt den største dårskab til at være visdom, så man kalder det oplysning "med Skygger af Jorden at formørke Herrens Lys". Denne falske "Oplysning" har ifølge Grundtvig haft til følge, at man har indbildt de kristne, "at Guds Ord om end i det Nye dog ei i det Gamle Testamente stod til Troende" (GP I, 127). Den polemiske front imod oplysningsteologien og den historiske kritik af bibelteksterne er her særdeles udtalt. Bibelkritikken udlægges som et udslag af vantro, som de kristne ikke skal lade sig forføre af.

Med særlig vægt kan Grundtvig fremhæve en bestemt typologisk sammenhæng, nemlig det gammeltestamentlige Israel som forbillede/type på den kristne menighed:

Saaledes vilde Apostelen, vi skulde betragte Israels Folk i alle Maader som Christi Menigheds Forbilleder, og minder derfor om, at den samme Aand var over dem som over os, prophetisk hos dem, som evangelisk hos os, at det var Christi Aand, at deres Ledsager, deres Befrier og Herre var saavelsom vores Christus selv; thi Han var aandelig i Verden fra Begyndelsen, skiøndt Verden kiendte ham ikke, ligesom han endnu er i Verden alle Dage, skiøndt Verden kiender ham ikke og seer ham ikke, fordi den kiender ikke Sandheds Aand (GP I, 128). 
Det gammeltestamentlige Israel er altså den kristne menigheds forbillede "i alle Maader". Hvad Det Gamle Testamente fortæller om israelitternes vandring gennem ørkenen mod det forjættede land, kan Grundtvig derfor også direkte overføre og anvende på kirkens historie og på dens nutid. Det gælder nemlig i lige så høj grad for den kristne menighed, at dens vej til det hellige forløber gennem en ørken, hvor hjertet fristes og troen prøves $(G P \mathrm{I}, 129)$.

Vi ser her, hvordan udgangspunktet for Grundtvigs typologiske tolkninger i flere tilfælde er den udtrykkelige reception af gammeltestamentlige tekster og motiver, som finder sted i nytestamentlige tekstsammenhænge. Den typologiske forbilledlighed, som tilskrives de gammeltestamentlige personer og begivenheder, kombineres hos Grundtvig med forestillingen om en stigning fra det gamle til det nye, byggende på den forudsætning, at det nye overgår og overstråler det gamle. Denne udformning af den typologiske model er også velkendt fra traditionen, idet den udgør en variation over motivet forjættelseopfyldelse.

I en prædiken til skærtorsdag 1823 stiller Grundtvig de jødiske og de kristne sakramenter over for hinanden: Omskærelsen og den jødiske påske sættes over for dåb og nadver. Grundtvig begynder med at fastslå de jødiske sakramenters karakter af forbilleder: Jøderne er det eneste folk, der har haft noget, der ligner den kristne menigheds dåb og nadver, "tvende hellige Kiende-Mærker, hvorved de adskiltes fra alle Hedninger". Disse tegn er omskærelsen og påskelammet, "der knyttede sig til en Bestemmelse og til en Begivenhed, de ikke havde tilfælleds med noget andet Folk paa Jorden" (GP I, 189). Omskærelsen er givet som tegn på Guds pagt med Abraham, hvis indhold er, at han vil give Abraham og hans afkom Kanaans land og være deres gud. Påskelammets nydelse skal minde om folkets underfulde frelse i Ægypten. Disse skikke udviser en mærkværdig lighed med dåben og nadveren: Den kristne dåb er et tegn på, at Gud vil være de kristnes Gud og arvinger til "det aandelige Canaan". Nadveren er indsat "til en bestandig Amindelse om den Skaansel og Frelsning som os er vederfaret i det aandelige Ægypten, i Syndens og Dødens Land, formedelst hans Blod, som døde for vore Synder". Efter at have konstateret de gammeltestamentlige sakramenters forbilledlighed og lighed med dåb og nadver går Grundtvig nu videre til at forklare den afgørende forskel imellem det gamle og det nye. Både de jødiske og de kristne sakramenter er tegn, men de kristne sakramenter er tillige mere end tegn:

Men vil vi see det Samme klarere, og lære at skatte de christelige Sacramenter efter deres sande Værd, da skal vi betænke, at vore Sacramenter vel ere Tegn, saavelsom Jødernes, skiøndt af en klarere høiere Art, men at de ingenlunde ere blotte Tegn, men tillige noget 
langt større. De ere Tegn forsaavidt der med synlige Ting skeer en legemlig Handling med en høiere, billedlig Betydning forsaavidt nemlig Vandet i Daaben betegner den rensende, helliggiørende Aand, som Gud i Jesu Navn vil udgyde over os, og forsaavidt Brød og Viin i Nadveren betegner Frelseren, som hengav sit Legeme og udøste sit Blod for os. Men med disse synlige Ting og Tegn er noget Usynligt forbundet; thi vore Sacramenter forrettes ikke tause, men under Fremførelse af det underfulde Usynlige, som er lagt paa vor Tunge til at forbinde Aand og Legeme, det er Ordet, og her ikke vores afmægtige Ord, men Jesu Almagts-Ord, om hvilke han vidner: De ere Liv og Aand (GP I, 190-191).

De kristne sakramenter er "ikke blot Tegn paa den Forbindelse som skal være mellem Gud og os", men "virkelige Baand, som knytte os til Gud og Frelseren i Aand og Sandhed" (GP I, 191). Derfor kaldes de da også med rette for nådemidler, hvorimod de gammeltestamentlige sakramenter - omskærelsen og påskelammet - var, hvad Grundtvig kalder nådetegn. Det, som kendetegner nådetegnene i modsætning til nådemidlerne, er, at de ikke er i stand til at virke med "saliggiørende Kraft". De må derimod stedse ses i sammenhæng med ofringerne og den samlede gudsdyrkelse og forstås i lyset af det profetiske ord. Her henviser Grundtvig udtrykkeligt til Jeremias-profetien om den nye pagt (Jer 31,31-34) (GP I, 191-192).

Grundtvigs typologiske tolkningsmodel opererer tydeligvis på den ene side med en kontrast imellem det ydre og det indre, på den anden med en kontrast imellem tegn og virkelighed. Det, der fortælles om i Det Gamle Testamente, er begivenheder, der udspiller sig på et udvortes, legemligt plan, medens det, begivenhederne viser hen til - den kristne sandhed - foregår på et indre, åndeligt plan. Den åndelige sandhed udgør nu den egentlige, sande virkelighed, medens de ydre begivenheder netop har karakter af henvisende tegn. Således kan Grundtvig i en udlægning af Første Korintherbrev 10 sige, at "Guds øiensynlige Førelser med dem betegne Hans usynlige, aandelige Førelser med os, Hans Folk i det Ny Testamente"(GP III, 202).

Også et andet klassisk fortolkningsskema, forjættelse-opfyldelse, finder rig anvendelse i Grundtvigs prædikener, igen ganske særlig i prædikenerne fra Vor Frelser-tiden. På Kristi himmelfartsdag 1823 kan Grundtvig således stille en formelig række af gammeltestamentlige forjættelser op og erklære dem for opfyldte med Kristi komme. Rækken af profetiske udsagn indledes med 1 Mos 3,14 (henvisningen til "Kvindens Sæd", der skal "sønderknuse Slangens Hoved") og fortsætter med henvisninger til Salme 118 ("det er sked af Herren skiøndt det er underligt for vore Øine"), Es 7,14 "en Jomfru blev frugtsommelig og fødte en Søn, hvis Navn er Immanuel”), Jer 31,21 ("Opreis dig Mindesmærker, stadfæst Ihukommelsen, sæt dit Hjerte til 
den banede Vei") og Salme 89, som er den tekst, der citeres mest udførligt (GP I, 259-260).

Vi møder her i Grundtvigs tidlige prædikener en række eksplicitte tematiseringer af spørgsmålet om Det Gamle og Det Nye Testamente. Det sker navnlig i form af apologetik for den bibelske sandhed og for sammenhængen imellem Bibelens to dele, loven og evangeliet. Denne tematik udfoldes i tilslutning til den klassiske lutherske dogmatiks begreber i prædikenen på søndag efter nytår 1823, hvor Grundtvig på karakteristisk måde udtrykkelig forsvarer troen mod de vantro, der hævder, at forkyndelsen af Guds nåde og retfærdiggørelse ved troen alene er en afvigelse fra Jesu egen rene lære: Loven og evangeliet modsiger ikke hinanden, men stadfæster hinanden. Loven viser hen til "Naade-Stolen" ved at afsløre synden i dens vederstyggelighed og er således en tugtemester til Kristus (GP I, 103-111).

I prædikenerne fra de senere år spiller den direkte udtrykkelige brug af Det Gamle Testamente som nævnt før en mindre fremtrædende rolle hos Grundtvig. Man kan til gengæld her med stor ret bruge Christian Thodbergs formulering om Grundtvigs prædikener, at de "er bibelske på en sådan måde, at man - paradoksalt udtrykt - ikke mærker det" (Thodberg 1998, 61). Det betyder på ingen måde, at de egentlige referencer til Det Gamle Testamente forsvinder ud af Grundtvigs prædiken. Således kan han på fastelavnssøndag 1832 gøre ordene fra Esajas 62: "For Zions Skyld vil jeg ikke tie" til prædikenens ledemotiv og anvende ordene direkte på den kristne menigheds nutid (GP V, 74-83). På tilsvarende måde er udgangspunktet for Grundtvigs langfredagsprædiken samme år salmistens ord (fra Salme 118): "Jeg skal ikke døe, men jeg skal leve og fortælle Herrens Gierninger" (GP $\mathrm{V}, 143) . \mathrm{Og}$ i sin påskeprædiken 1832 kan Grundtvig lade ordene fra den samme gammeltestamentlige salme "Denne er Dagen som Herren gjorde" vokse til et helt orkester af gammeltestamentlige profetiske billeder, der "Dag for Dag klarere opfyldes paa dem der blive ved Christum" ( $G P \mathrm{~V}, 156)$. Her får det gammeltestamentlige billedsprog så at sige en dobbelt betydning, når det læses og tolkes ind i den kristne menigheds sammenhæng.

\section{Eksempler på brugen af gammeltestamentlige motiver i Grundtvigs salmedigtning}

Et tidligt eksempel på en gendigtning af en gammeltestamentlig tekst er "Som tørstige Hjort monne skrige". I digtet, der stammer fra 1811, 
bearbejder Grundtvig Salme 42-43. ${ }^{6}$ Det billede, der indleder Grundtvigs første strofe, er direkte overtaget fra den gammeltestamentlige salme: "Ligesom en Hjort skriger efter Vandstrømme, saa skriger min Siel til dig, o Gud" (Sl 42,2):

Som tørstige Hjort monne skrige,

Alt efter det rindende Væld,

Saa monne og efter dig hige,

O Herre, min tørstige Sjæl (GSV III, nr. 35).

Den kulturhistoriske baggrund for billedet i Salme 42 er den mellemøstlige wadi, der strømmer med vand, når regnen er faldet, men ellers ligger udtørret hen. Grundtvig har med få og enkle midler omsat billedet til en anden kultur og et andet klima: Ved en let omformning af billedet er det udtørrede flodleje forsvundet, til gengæld udtrykkes i Grundtvigs linjer positivt, hvad det er tørsten og længslen retter sig mod, nemlig: "det rindende Væld". Dette billede udfolder Grundtvig i strofens følgende linjer: "Thi du er den levende Kilde, / Og drikke saa gerne jeg vilde / For aldrig at tørste igen." Her alluderer Grundtvig til en anden bibelsk sammenhæng, nemlig beretningen i Johannesevangeliet om Jesu møde med den samaritanske kvinde ved Jakobskilden. "Dersom du kiendte Guds Gave, og hvo den er, som siger til dig: giv mig at drikke, da bad du ham, og han gav dig levende Vand" (Joh 4,10). "Hver den, som drikker af dette Vand, skal tørste igien. Men hvo, som drikker af det Vand, som jeg vil give ham, skal til evig Tid ikke tørste; men det Vand, som jeg vil give ham, skal blive i ham en Kilde af Vand, som opvælder til et evigt Liv" (Joh 4,13-14). Det er dette billede af den levende kilde, som dominerer den sidste del af strofen. $^{8}$

Anden strofe af Grundtvigs salme er en gendigtning af salmistens linjer: "Naar skal jeg komme derhen, og sees for Guds Ansigt. Min Graad er min Mad Dag og Nat, fordi man siger den ganske Dag til mig: hvor er din Gud?" (Sl 42,3-4):

6 Digtet blev trykt forste gang i samlingen Saga. Nytaarsgave for 1812, der udkom den 23. december 1811.

7 Bibelcitaterne er fra Christian VI's bibel.

8 Meget kunne i øvrigt tyde på, at her var tale om et af Grundtvigs yndlingsbilleder. I hvert fald dukker det op på et centralt sted i NyaarsMorgen i indledningen til tredje sang, hvor Grundtvig taler om dåbens og kristendommens blivende betydning med ordene: Det Næste, jeg mindes, / Det var ingen Drøm, / Thi i mig end findes / Den levende Strøm, / Som læsker og kvæger / Med Væde fuldsød, / Som dybt mig bevæger, / I Lyst og i Nød” (US IV, 260). 
De Dage og Nætter henskride,

Og Sjælen kun lædskes med Graad,

Med Sorrig jeg Hænder maa vride,

Jeg veed ikke Frelse, ei Raad.

I Grundtvigs gengivelse er der intet spor af det typiske gammeltestamentlige motiv med fjenderne eller spotterne, der omgiver salmisten og trænger ind på ham med deres spørgsmål. Til gengæld bliver sangerens eller jegets egen fortvivlelse bredt udfoldet med afsæt i den gammeltestamentlige tekst. Grundtvig har sat salmistens retoriske spørgsmål om, hvornår han må se Guds ansigt, som en effektfuld konklusion på klagen i anden strofe.

I tredje strofe er de geografiske henvisninger ("Min Siel nedbøier sig i mig, derfor vil jeg komme dig ihu fra Jordans Land og Hermonium, fra det lille Bierg") erstattet med den generelle reference til afgrundenes rand:

Jeg er udi Hjertet saa bange,

De Afgrunde ligge saa nær,

Og paa deres Rand maa jeg gange,

Det er kun en jammerlig Færd.

I den gammeltestamentlige sammenhæng antyder stednavnene fjernheden fra Guds helligdom og salmistens fjernhed eller perifere placering i forhold til det forjættede land. Det er nærliggende at forestille sig, at baggrunden for salmistens billedsprog er en form for symbolsk geografi, en sammentænkning af teologi og geografi, hvor Jerusalem med helligdommen er opfattet som landets centrum, hvorfra helligheden breder sig udad. Grundtvig synes at have lånt billedet af afgrunden, der formentlig er i hvert fald vagt inspireret af hentydningen til bjerglandskaber i salmeteksten.

Den gammeltestamentlige salmist afbryder flere gange sin klage med en tilbagevendende tillidserklæring: "Hvorfor nedbøier du dig, min Siel, og bruser over mig? Bi efter Gud, thi jeg skal endnu takke ham; for han er mit Ansigts megen Frelse og min Gud" (Sl 42,6.12; 43,5). Grundtvig låner dette motiv og kombinerer det virkningsfuldt med billedet af Gud som klippen, som også er taget fra salmistens billedsprog. "Jeg vil sige til Gud: min Klippe, hvorfor haver du glemt mig?" (Sl 42,10). I Grundtvigs fjerde strofe kan vi også fornemme en vis indflydelse fra nytestamentligt billedsprog:

Du er jo min Saligheds Klippe,

Paa dig har jeg bygget mit Hus,

Ak, vil du mig glemme og glippe,

Da synker det flux udi Grus;

Alt bryde de Bølger og Vover, 
Og medens du tøver og sover,

De lukke sig over min Sjæl.

Jesu ord til Peter: "Du er Petrus, og paa denne Klippe vil jeg bygge min Menighed, og Helvedes Porte skulle ikke faae Overhaand over den" (Matt 16,18) klinger umiskendeligt med hos Grundtvig. Lige så tydelig er afsmitningen fra et andet nytestamentligt billede, Jesu lignelse om de to huse, huset, der er bygget på klippen, og huset, der er bygget på sand (Matt 7,24-27). Herfra stammer det dobbelte billede af huset, der er bygget på klippen, og huset, der synker i grus. Hos Grundtvig er de to størrelser tænkt sammen til et og det samme hus, der symbolsk repræsenterer salmistens afhængighed af Gud.

Motivet med Gud, der tøver og sover, leder tanken hen på stormen på søen (Matt 8,23-27). Samtidig rummer billedet også mindelser om de gammeltestamentlige opfordringer til Gud om at rejse sig og ikke forholde sig tavs og inaktiv $\mathrm{i}$ forhold til salmistens trængsel. Grundtvigs billedbrug her er med andre ord et eksempel på, hvordan forskellige bibelske baggrunde smelter sammen og bliver til et bibelsk billedsprog.

I salmens femte strofe bliver det gammeltestamentlige billede omplantet til dansk jord. Den gammeltestamentlige salmist genkalder sine tidligere pilgrimsvandringer til helligdommen: "Disse Ting vil jeg komme ihu, og udøse min Siel hos mig selv; thi jeg vilde gaae frem med Hoben, vilde gaae afsted med dem til Guds Huus, med Frydeskrigs- og Taksigelses-Røst, iblandt den Hob, som holder helligt" (Sl 42,5). Hos Grundtvig sidder jeget alene tilbage i sin hytte, medens de andre begiver sig ad kirkestien søndag morgen:

Naar Andre til Kirke mon gange,

Da sidder jeg her udi Vraa,

De kvæde saa liflige Sange,

Men jeg maa ei høre derpaa.

Grundlæggende er der tale om den samme udelukkelse fra fællesskabet, den samme ufrivillige isolation, som er motivet i den gammeltestamentlige tekst. Igen er det kulturhistoriske skifte afstedkommet effektivt med meget enkle midler. Hos Grundtvig er helligdage og søgnedage blevet en forskelsløs masse, bestemt af sangerens nød: "Min Sang er at sukke og klage, / Saa skride de hellige Dage / For mig, som de søgne, i Kval."

I Grundtvigs sjette strofe er det den gammeltestamentlige salmes typiske tillidserklæring, der afspejles i slutlinjerne: "Engang skal den Morgen oprinde / Da frelst du saa glad udi Sinde / Skal takke og love din Gud." Morgenen er her et billede på Guds nye begyndelse, samtidig med, at der formentlig også skal tænkes på opstandelsens morgen. 
Syvende strofe lægger sig i første omgang ganske tæt op af den gammeltestamentlige tekst: "Send dit Lys og din Sandhed, at de, de maae ledsage mig, at de maae føre mig til dit hellige Bierg og til dine Boliger, og at jeg maa indgaae til Guds Alter, til min Fryds Glædes Gud, og takke dig paa Harpe, o Gud, min Gud" (Sl 43,3-4): "Hans Lys og hans Sandhed skal føre / Mig op til hans Tempel i Fred." Templet er i Grundtvigs sammenhæng blevet et ikke-konkret sted, et universelt symbol på Guds nærvær. I en vis forstand kan Grundtvig siges at befinde sig på linje med det gammeltestamentlige billedsprog og salmens tempelsymbolik. Samtidig får symbolikken et kristent indhold, skønt Grundtvigs salme ikke har nogen direkte henvisning til Kristus eller Det Nye Testamente.

I den noget senere salme "Hyggelig, rolig" (1836), en gendigtning af Salme 84, holder Grundtvig sig ganske nær til den gammeltestamentlige salmes grundlæggende struktur og overordnede tankegang. ${ }^{9}$ Indledningslinjerne i første strofe er i sig selv karakteristiske for Grundtvig med deres brug af "hyggelig". Salme 84 indledes med ordene: "Hvor elskelige ere dine Boliger, Herre Zebaoth! Min Siel begierer og længes ogsaa at komme til Herrens Forgaarde; mit Hierte og mit Kiød raabe med Fryd til den levende Gud" (Sl 84,1-3). Motivet får hos Grundtvig en lidt anden nuance med ordene "hyggelig, rolig" som indledning. Det er motivet hvile, ro, der her er sat i spidsen for det hele og kommer til at bestemme det øvrige. Guds bolig er et sted, hvor hjertet finder hvile og ro.

Anden strofe henter billedet med svalen og spurven, der finder deres bolig ved Herrens altre, fra den gammeltestamentlige salme ( $\mathrm{Sl}$ 84,4). Grundtvig foranstiller imidlertid billedet af Gud som "Godhedens Kilde":

Godhedens Kilde!

Aarle og silde

Giæstmild er Du!

Ved dine Sale

Spurv møder Svale,

Kom det ihu! (GSVI, nr. 61).

Kildebilledet kan være inspireret af salmistens skildring af valfartsvandringen gennem tørre egne. "Naar de gaae igiennem Morbærdalen, sætte de ham for sig til en Kilde, ja, og en Regn med Velsignelser skal bedække dem. De skulle gaae fra Kraft til Kraft; Hver af dem skal sees hos Gud i Zion" (Sal 84,7-8). Til gengæld er hele valfartsmotivet er fraværende i Grundtvigs gendigtning. Der kan

Digtet blev trykt første gang i Nordisk Kirke-Tidende 1836. Jf. Johansen, I, 1948, 316. Jf. GSV VI, 1956, 24-25. 
være flere forklaringer. Dels er der den kulturhistoriske distance, som adskiller Grundtvigs danske virkelighed fra det gammeltestamentlige univers. Stednavne og hentydninger til Palæstinas forhold er borte i gendigtningen. Det er umiddelbart nærliggende at forstå dette træk som et forsøg på at undgå unødvendige afstandsskabende eller fremmedgørende faktorer. Herudover kan det tænkes, at valfarts- og vandringsbilledet ikke passede ind i den sammenhæng, som Grundtvig her ville have frem: I "Hyggelig, rolig" er der snarere tale om en modstilling af livet i Guds helligdom og nærvær, som allerede er virkelighed for salmens jeg (str. 2-3), og den jordiske tilværelse, hvor jeget kan kikke ind i Himmerig, og hvor Gud i hans hjerte bygger en trappe til Himmerigs sal (str. 4). Måske er det rigtigere at tale om, at valfartsmotivet så at sige transformeres til et eskatologisk motiv, hvor den egentlige "bevægelse" får et transcendent mål. Det ville passe til str. 5, der ikke taler om en vandring, men derimod nok om en opstigen til "Høieloft". Her trækker Grundtvig på det klassiske visio beatificabillede, hvor et menneskes salighed består $i$ at skue Gud $i$ hans herlighed. Grundtvigs brug af billedet her har en tydelig eskatologisk dimension og indbefatter forestillingen om de sidste tider: Billedet af "Øiet, som græder ei meer", er formentlig inspireret af ordene i Johannes' Åbenbaring om, at Gud "skal aftørre hver Taare af deres Øine" (Åb 21,4). Sammenhængen her taler om, at Guds bolig skal være hos menneskene, og døden skal ikke være mere.

Sjette strofe bygger på salmistens kontrast: "Thi een Dag er bedre $\mathrm{i}$ dine Forgaarde end ellers tusinde" ( $\mathrm{Sl} \mathrm{84,11).} \mathrm{Billedet} \mathrm{kombineres} \mathrm{hos}$ Grundtvig med et andet motiv, nemlig sjælens himmelfart "over Stjernerne". Der består på samme tid en spænding og samtidig en forbindelse imellem det jordiske og det himmelske:

Tusinde Døgne,

Verdslige, søgne,

Gyldne for Kiød,

Kan de vel ligne

Een Dag af dine,

Som vi dem nød,

Naar under Sang, med dit vingede Ord,

Sjælen afby over Stjernerne foer?

Syvende strofe er dannet over ordene: "Jeg udvælger heller at være hos Dørtærskelen i min Guds Huus, end at boe i de Ugudeliges Pauluner" (Sl 84,11). Hos Grundtvig er enhver antydning af gensidighed eller moralistisk gengældelse borte. I stedet er hele billedet koncentreret om Guds nåde. Strofens afsluttende linjer er en understregning af Guds nådes virkelighed også under de jordiske 
forhold: "Godt ikke fattes hvem Gud haver kiær! / Lavt er ei bænket, hvem Du sidder nær!"

Grundtvigs ottende og sidste strofe har sin baggrund i den gammeltestamentlige teksts linjer: "Thi den Herre Gud er Sol og Skiold; Herren skal give Naade og Ære, han skal intet Godt vægre dem, som vandre i Fuldkommenhed. Herre Zebaoth! Saligt er det Menneske, som forlader sig paa dig." Grundtvig lader det nytestamentligt inspirerede begrebspar sandhed og nåde (Joh 1,14) tolke salmens gudsbillede; og til tanken om Guds omsorg føjer han en eskatologisk dimension:

Sandhed og Naade,

Det er din Gaade,

Stor-Herre bold!

Salig at prise

Er den Retvise,

Du er hans Skjold,

Øie Du holder med salvede Smaa,

Til for dit Ansigt de kronede staae!

I "Kirken det er gammelt Huus" (1837) gør Grundtvig udstrakt brug af tempelsymbolik og i det hele taget af både gammel- og nytestamentlige motiver. ${ }^{10}$ Første strofe begynder $i$ det konkrete billede: Kirkebygning og kirke beskrives som en struktur i forfald, præget af forgængelighed, de konkrete udformninger skifter, synker i grus og erstattes, men samtidig med forgængeligheden og omskiftelserne er der også tale om kontinuitet, udtrykt i kirken, der bliver stående, medens tårnene falder, og i klokkernes vedvarende kalden (str. 1). Her er tale om et mønster, der udspiller sig i hver eneste generation. ${ }^{11}$ Samlet fremstår et plastisk billede, der kommer til at handle om kirken som underlagt historiens vilkår, forgængelighed og foranderlighed.

Anden strofe har form af et tilbageblik på den gammeltestamentlige helligdom. Strofen rummer en tydelig allusion - om et egentligt citat kan man vel ikke tale her - til Første Kongebog 8. Salomos ord om Gud, der ikke bor på jorden, og som himlene ikke kan rumme (1 Kong 8,27), er utvivlsomt inde i billedet. Desuden kastes der et tilbageblik på åbenbaringsteltet eller ørkenhelligdommen (“ArkePaulunet"):

10 Digtet tryktes i Sang-Vark til den Danske Kirke (1837). Den oprindelige titel lyder "Kirken det er et gammelt Huus." Jf. Malling (1963), 118. Se også den (ufuldstændige) liste over bibelske citater og allusioner (ibid., 118-119).

11 Det kan ikke udelukkes, at den skæbne, der var blevet Københavns kirker - især Vor Frue Kirke - til del ved bombardementet i 1807, kan have spillet en rolle for billedets konkrete udformning. 
Herren vor Gud vist ei beboer

Huse, som Hænder mon bygge,

Arke-Paulunet var paa Jord

Kun af hans Tempel en Skygge (GSV I, nr. 22).

Skyggemotivet er hentet fra Hebræerbrevet: Loven indeholder en skygge af de kommende goder (Heb 10,1). "Hans Tempel", som ørkenhelligdommen var en skygge af, må her være Guds himmelske helligdom (ikke templet i Jerusalem). Som kontrast til "ArkePaulunet" henviser Grundtvig nu til den underfulde bolig, som Gud selv rejser "af Støv og Muld". Denne bolig leder tanken hen på det nytestamentlige motiv: helligdommen, som ikke er gjort med hænder (Mark 14,58; 15,29). Det nye, sande tempel er Kristus selv, men også hans menighed på jorden, de to størrelser er knyttet sammen gennem legeme-symbolikken. Her hos Grundtvig er der efter alt at dømme først og fremmest tænkt på menigheden, hvad der fremgår af understregningen af støv og muld. Gud rejser sin underfulde helligdom af dødeligt, forgængeligt stof. Menigheden som Herrens tempel er en figur, der har sin baggrund i Det Ny Testamente (1 Kor 3,16); og det er denne symbolik og det billedsprog, der er knyttet til den, der fortsætter i den følgende strofe. Her (i str. 3) introduceres det nytestamentlige tempelbillede fra Første Petersbrev: Den kristne menighed ses som et åndeligt hus af levende sten (1 Pet 2,4-5). Og Grundtvig kan her slet ikke lade være med at tilføje en præciserende bestemmelse af, hvad det er, der definerer den kristne menighed, nemlig troen og dåben, og en bestemmelse af, hvad der er menighedens vilkår i verden, nemlig korset. I strofens sidste linjer indfører Grundtvig motivet fra Jesu forjættelse: "Hvor To eller Tre ere forsamlede i mit Navn, der er jeg midt iblandt dem" (Matt 18,20). Grundtvig drager den radikale konsekvens, at Jesu menighed på hele jorden kunne bestå af to mennesker; stadigvæk ville han bygge og bo i sit tempel "i hele sin Vælde". ${ }^{12}$ Samlet set kommer strofens sidste linjer til at fungere som en understregning og uddybning af kontrasten imellem Guds underfulde gerning, når han rejser sin bolig, og det forgængelige støv og muld, han bygger sin helligdom af.

Fjerde og femte strofe er en reflekterende overvejelse/meditation, der handler om, hvad det vil sige, at vi, den kristne menighed, er "Guds Huus og Kirke". Betydningen forklares i første omgang som

12 Samtidig synes Grundtvig også at trække en typologisk linje tilbage til de to første menneskers situation: Før syndefaldet var der kun to mennesker Adam og Eva - på jorden; og dengang boede Gud i hele sin vælde hos menneskene. Grundtvig lægger i anden sammenhæng vægt på, at frelsen også omfatter vore første forældre; og man kan muligvis også finde en antydning af dette motiv her. 
det, at frelseren selv kommer til sin menighed, når den mødes og påkalder hans navn. ${ }^{13}$ Det leder over til versets afsluttende udsagn om Kristi nærvær, igen en allusion til en gammeltestamentlig tekst: "Thi det Ord er saare nær hos dig, i din Mund og i dit Hierte" (5 Mos 30,14). Paulus citerer i øvrigt den samme tekst i Rom 10,8: "Nær som sit Ord, i allen Stund, / Han er vort Hjerte og vor Mund, / Drot over Tiden og Rummet."

Femte strofe fortsætter med udsagnet om, at vi - Kristi menighed på jorden - kan samles med vor drot. Dette fællesskab er ikke begrænset af noget ydre forhold eller vilkår, men finder sted "selv i den laveste Hytte". Der er ikke noget særligt ydre forhold, der danner betingelse for den kristne menigheds gudstjeneste. Grundtvig hentyder til beretningen om forklarelsen på bjerget, hvor Kristus viser sig for sine udvalgte disciple $i$ et forvandlingens lys, omgivet af Moses og Elias, hvad der får Peter til at udbryde: "Herre! Her er godt at være" (Matt 17,4). Peters ord om, at han vil bygge tre hytter på bjerget til Jesus, Moses og Elias, bliver ofte tolket som udtryk for en vis naivitet eller ligefrem som udslag af en dybest set misforstået trang til at fastholde det guddommelige under i jordiske rammer. Her forstår Grundtvig imidlertid udsagnet positivt som et udsagn talt ud af den kristne menigheds tro eller som en bekendelse.

Som en modsætning ("dog") eller i hvert fald en eftertanke kommer Grundtvig i sjette og syvende strofe tilbage til de jordiske kirkebygninger, til historien og forgængelighedens verden. Både det enkelte menneskes historie og slægtens historie er knyttet til ydre, konkrete steder, der også bliver vidnesbyrd, erindringer om det hørte og skete. Ottende strofe er en applikation: Kirkens yderside har fået gennemsigtighed, synlig og usynlig virkelighed danner en helhed. Det afsluttende udsagn (niende strofe) er dog igen en udtrykkelig understregning af, hvordan den egentlige kirke er "Kirken af levende Stene", som forenes af troen og dåben og helliges af ordet.

Et andet meget tydeligt eksempel på den for Grundtvig typiske transparens, hvor gammel- og nytestamentlige tekster så at sige bliver lagt oven på hinanden, så de kommer til at gennemlyse hinanden, finder vi i "Tør end Nogen ihukomme" (1825). ${ }^{14}$ Det ihukommelsesmotiv, der fra første linje etableres som bestemmende for digtet, har

Grundtvigs fjerde strofe er ikke medtaget i Den Danske Salmebogs udgave af salmen, men de sidste linjer af strofen er til gengæld brugt som afslutning på salmens fjerde strofe (= femte strofe i 1837-udgaven). Om de forskellige udgaver af salmen i diverse salmebøger, jf. Malling (1963), 119.

14 Digtet blev under titlen "Zions Sang” første gang trykt som indledningsdigt i tredje bind af Theologisk Maanedsskrift (Malling 1966, 66). Om forkortelser og ændringer i diverse salmebogsudgaver, se ibid. (68-69). 
tydeligvis sin baggrund i Salme 137, hvorfra henvisningen til "Zions Sang” også stammer. De retoriske spørgsmål i første strofe kan læses som en parafrase over fjendernes opfordring til de bortførte israelitter i den gammeltestamentlige salme: "Synger for os af Zions Sang" (S1 137,3). I Grundtvigs strofe er det imidlertid "Zions Sang", der bliver genstand for ihukommelsen. Det tre gange gentagne "end" placerer den gammeltestamentlige situation eftertrykkeligt $i$ et fortidigt perspektiv.

Striben af retoriske spørgsmål besvares $\mathrm{i}$ anden strofe med et fuldtonende "ja" og en henvisning til "Christi Kirke" som stedet, hvor Zions sang skal lyde og Zion ihukommes med "Taaren varm". Hermed er erindringens udgangspunkt, den nutid, ud fra hvilken den gammeltestamentlige fortid erindres, klart angivet. I salmens tredje strofe er det henvisningen til Israels fjender i Salme 137, der danner baggrund:

Trodser kun, I Kirke-Fiender!

Larmer kun, I Edoms Børn!

Laver kun, mens Taaren rinder,

Giæstebud til Ulv og Ørn!

Tone over eders Grave

Skal dog Zions Fryde-Sang,

Og er Harpen i Ulave,

Læmpes til Basune-Klang! (GSV I, nr. 13).

Den gammeltestamentlige teksts edomitter går hos Grundtvig $i$ et med den kristne nutids "Kirke-Fiender". Henvisningen til Babylons datter og det grotesk udmalede hævnmotiv ("Salig den, som griber, og slider dine spæde Børn paa en Klippe") i Sl 137,8-9 tages ikke op; til gengæld stilles "Zions Fryde-Sang" i modsætning til fjendernes ødelæggelser. Fjerde strofe retter fokus mod "Herrens Bjerg", som fjenden er nødt til at lade stå. Motivet rummer genklange af Salme 46 (og udtrykket "Herrens Bjerg han lod dog staae" er inspireret af Luthers gendigtning "Vor Gud han er saa fast en Borg"). Den centrale henvisning til hjørnestenen, som hele tiden har ligget fast, og som modstår ethvert angreb, er hentet fra Es 28,16. Grundtvig forudsætter selvsagt den klassiske kristne fortolkning af den kostelige hjørnesten som Jesus Kristus selv (1 Pet 2,6-8). Strofen gør det velkendte gammeltestamentlige motiv, hvor Guds bjerg modstår fjendernes angreb, til et billede på den kristne menighed, som i Kristus har den virkelige, urokkelige hjørnesten. Lige så lidt som Israel er kirken dog usårlig. Fjenden hærger sletten - der er altså et vidstrakt område uden for bjerget, som er udsat for den ødelæggelse, der blev henvist til i str. 3. Motivet "Hjørne-Stenen" bliver nu udgangspunkt for salmens afgørende vending: 
Taare-Sky! Ei saa du hænge

Over Bjerget sortegraa!

Skil dig ad, lad Straalen trænge

Ud dog under dunkle Braa,

Saa vi skue den Skyklædte,

Med sin favre Regnbu-Krands!

I et Øie bedre stædte

Herren aldrig Sole-Glands.

Da skal løses brat vor Tunge,

Som forstummed under Graad,

Sødt om Adel-Stenen sjunge,

Som det var Guds vise Raad

Til en Grundvold god at lægge

I det stolte Zions-Slot,

Som har Himlen til sit Dække,

Guds Eenbaarne til sin Drot!

Her identificeres Hjørnestenen udtrykkeligt som "Guds Eenbaarne". Kristus kaldes også (i str. 5) "den Skyklædte", en beskrivelse, der minder om skildringen af Menneskesønnen, der kommer "i Himmelens Skyer" i Dan 7,13. Gennem tåreskyen, der skilles, skuer salmens "vi" - menigheden - Kristus i hans herlighed. Således bliver den gammeltestamentlige fortid gennemsigtig i sin virkelige betydning, dvs. som "Guds vise Raad".

Syvende strofe introducerer et nyt motiv, nemlig opførelsen af en ny helligdom "paa den gamle Klippe-Grund". Her og i de følgende strofer er det beretningen i Ezra 3 om genopførelsen af Jerusalems tempel på de gamle grundvolde efter hjemkomsten fra det babyloniske eksil, der danner baggrund. Hos Grundtvig bliver denne forestilling imidlertid transparent eller dobbelttydig i den forstand, at her samtidig bliver tale om opførelsen af den nye helligdom, som er den kristne kirke. Interessant nok er det i dette tilfælde ikke overbuds-tanken, hvor den nytestamentlige opfyldelse overgår og overstråler den gammeltestamentlige type, der dominerer. Det gør derimod motivet fra Ezra 3, at det nye tempel står tilbage for det gamle i glans og pragt. Dette motiv skrives ud i salmens str. 8:

Ei skal Zions Borg sig høine

Denne Gang med Spir og Taarn,

Hyttelavt, i Verdens Øine,

Bygges nu imod tilforn,

Saa os efter Ham vi føie,

Som har sagt, Han vilde boe,

Hvor sig Stjerner for Ham bøie,

Og hvor blye Kiær-Minder groe. 
I forhold til det fortidige gammeltestamentlige Israel savner den kristne menigheds bygning ydre storhed set med verdens øjne. I sine prædikener benytter Grundtvig kontrasten imellem det ydre og det indre til at lade de udvortes, legemlige begivenheder i Det Gamle Testamente fungere som tegn på den kommende, indre eller åndelige virkelighed, der er knyttet til Kristus og hans kirke. I denne sammenhæng udfoldes motivet på en ny måde. Den ydmyghed eller ringhed (i det ydre), der knytter sig til det nye, kædes her direkte sammen med inkarnationen; Kristi komme i ydre, jordisk ringhed: Vi - menigheden - føjer os her efter Kristus selv. Str. 9 supplerer med et andet aspekt ved at henvise til "Huset med de høie Sale", som det kun er skaberens hånd, der tømrer, og som må dale ned fra himlen "som til Støvet Herrens Aand", medens "vi" kun bygger "et Giæste-Kammer / Til en himmelsk Alter-Gang". Her er det guddommelige og det menneskelige subjekt altså tydeligt adskilt: Gud selv bygger den egentlige helligdom, medens den kristne menighed bygger et gæstekammer til at modtage, hvad der daler ned fra himlen. Str. 10 vender tilbage til kontrasten imellem "Verdens Vise, Jordens Bolde", der foragter menighedens "Hytte", medens "den Største" vil holde nadver netop her. Igen henvises til inkarnationen: Kristus har krummet sig "Barneglad i Moder-Skiød" og vil bryde brødet i hytten. Og nu slutter Grundtvig af med at inddrage endnu en tekst fra Det Gamle Testamente, Hagg 2,6-9, en profeti, der taler om, hvordan "det sidste Huses Herlighed skal blive større end det førstes" (Hagg 2,9). Dette udsagn bliver hos Grundtvig læst sammen med kontrasten imellem "vort Bonde-Huus" og det tidligere tempel "med Borge-Gaarde", som her bliver et fortættet billede på den gamle pagts tid. Det, der kendetegner den nye helligdom, er "Herrens Fred", et udtryk, som også er hentet fra Haggaj-teksten ("og jeg vil give Fred i dette Sted, siger den Herre Zebaoth" (Hagg 2,9)), men som i Grundtvigs gendigtning bliver den fred, som Kristus skænker, som er "Meer end Guld". Igen tager Grundtvig sit afsæt i den gammeltestamentlige tekst ("Sølvet hører mig til, Guldet hører mig til, siger den Herre Zebaoth" (Hagg 2,8)) og går samtidig ud over denne ved at gøre Herrens Fred, som "vi" - den kristne menighed - skal forklares ved, til en størrelse, bestemt af en kristen teologis kontekst.

\section{Afsluttende bemærkninger}

Grundtvigs opfattelse af Det Gamle Testamente, som den fremstår i hans historiske værker, må kendetegnes som konservativt $\mathrm{i}$ den forstand, at han generelt tilkender de bibelske beretninger en høj grad af historisk sandhedsværdi. Han forsvarer jævnligt de gammel- 
testamentlige profetier som autentiske med kritisk brod mod samtidens rationalistiske bibelkritik. Imidlertid giver han i verdenskrøniken fra 1814 udtryk for et forholdsvis nuanceret og på flere punkter kritisk syn på den gammeltestamentlige kanon. Og i Haandbog $i$ VerdensHistorien I fra 1833 tager han direkte afstand fra det ortodokse syn på skriftens verbalinspiration og retter kritiske bemærkninger mod såvel rationalister som ortodokse teologer. Det Gamle Testamente vedbliver ikke desto mindre at have en meget stor betydning for Grundtvig igennem hele forfatterskabet. I sine prædikener gør han udstrakt brug af gammeltestamentlige citater; og i fortolkningen genfinder vi de klassiske modeller som typologi og forjættelse-opfyldelse. I de senere prædikener bliver de direkte citater færre; men samtidig gennemtrænges prædikenerne af både gammel- og nytestamentlige motiver og billeder. I Grundtvigs salmetekster finder der ligeledes en omfattende brug, fortolkning og omformning af gammeltestamentlige tekster og motiver sted. Ofte kombineres gammel- og nytestamentlige motiver og billeder, så de ikke alene kommer til at tolke og forklare hinanden, men ender med at indgå $\mathrm{i}$ et særegent fællesbibelsk billedsprog. Således er det ikke til at afgøre, om et billede som kilden eller det levende vand har en baggrund eller en reference, der primært skal søges i Det Gamle eller i Det Nye Testamente. Det er lige præcis helheden, den samlede bibelske overlevering, der må tænkes med for at få billedet til at give mening.

Gennem Grundtvigs salmedigtning fremtræder konturerne af et samlet bibelsk univers, der først og fremmest overbeviser i kraft af billedsprogets egen indre sammenhæng. I en vis forstand kan den fortolkning af Det Gamle Testamente, som finder sted i Grundtvigs salmer, dermed siges - i grunden på linje med Grundtvigs brug af Det Gamle Testamente i prædikenerne - at stå som en markant påstand om en sammenhæng, som ikke skal etableres eller forsvares med teologiske argumenter, men som foreligger som en historisk given kendsgerning i den kristne menigheds aktuelle virkelighed.

\section{Litteraturliste}

\section{Forkortelser}

GP I-XII: Chr. Thodberg (udg.) (1983-86), Grundtvigs Pradikener 1823-24, I-XII, København.

GSV I-VI: Th. Balslev m.fl. (udg.) (1944-64), Grundtvigs Sang-Vark. Samlet Udgave, I-VI, København.

US I-X: Holger Begtrup (udg.) (1904-09), Nik. Fred. Sev. Grundtvigs Udvalgte Skrifter, I-X, København.

VK 1814: N. F. S. Grundtvig, Kort Begreb af Verdens Krønike, betragtet $i$ Sammenhoeng Første Bind, København 1814. 


\section{Voerker af Grundtvig}

Balslev, Th. et al. (udg.) (1944-64), Grundtvigs Sang-Vark, I-VI, København. Grundtvig, N. F. S. (1812), Kort Begreb af Verdens Krønike i Sammenhoeng i US II, 167-422.

- (1814), Kort Begreb af Verdens Krønike, betragtet i Sammenhoeng. Første Bind, København.

- (1833), Haandbog i Verdens-Historien. Efter de bedste Kilder. Et Forsøg I (Oldtiden) i US VI, 7-531.

Thodberg, Chr. (udg.) (1983-86), Grundtvigs Proedikener 1823-24, I-XII, København.

\section{Verker af andre forfattere}

Balslev-Clausen, Peter (2002a), "Davids-salmer gendigtet på dansk", Hymnologiske Meddelelser, 31(1), 1-48.

- (2002b), "Davidssalmer i de danske salmebøger" i Holt og Nielsen (2002), 207-225.

Barr, James (1981), Fundamentalism, 2nd edition, London.

Begtrup, Holger (1901), N. F.S. Grundtvigs kirkelige syn 1825. En historisk indledning, København.

Holt, Else Kragelund (red.) (1998), Alle der ånder skal lovprise Herren! Det Gamle Testamente i tempel, synagoge og kirke, Frederiksberg.

Holt, Else Kragelund, og Nielsen, Kirsten (2002), Dansk Kommentar til Davids Salmer I, København.

Johansen, Steen (1948-1954), Bibliografi over N. F. S. Grundtvigs Skrifter 14. Kobenhavn.

Malling, Anders (1963), Dansk Salmehistorie, III, København.

- (1966), Dansk Salmehistorie, V, København.

Pedersen, Kim Arne (2005), "Grundtvig og fundamentalismen", GrundtvigStudier 2005, København, 86-124.

Pedersen, Sigfred (red.) (1989), Skriftsyn og metode. Dansk Kommentar til Det Nye Testamente (DKNT) 1, Aarhus.

Rosendal, Bent (2006), "Grundtvig forkynder Israels historie", Dansk Teologisk Tidsskrift, 69, 144-156.

Simonsen Hejne (1983), "Grundtvig som ekseget" i N. F. S. Grundtvig Theolog og Kirkelcerer. Udgivet af Udvalget for Konvent for Kirke og Theologi, Skarrild 1983, 20-32.

Thodberg, Christian, "Grundtvigs bibelsyn" i Pedersen 1989, 126-142.

- (1998), "Grundtvig og Gammel Testamente - den danske Bibel eller Septuaginta?", Grundtvig-Studier 1998, København, 61-80.

Vind, Ole (1992), Grundtvigs historiefilosofi, København.

Wigh-Poulsen, Henrik (1998), “'Hør mig, I fjerne øer' - Esajas, Grundtvig og det danske landskab" i Holt 1998, 259-286.

Artiklen er en kraftigt revideret udgave af et foredrag holdt i Teologisk Forening, København, september 2007. 